\title{
気候変動予測値に基づく九州沿岸における 災害外力の変動特性に関する検討
}

\author{
横田 雅紀 1 ・橋本 典明 2 ・山根 知洋 3 ・児玉 充由 4 \\ 1正会員 九州大学助教 大学院工学研究院（†819-0395 福岡県福岡市西区元岡744） \\ E-mail:yokota.masaki.426@m.kyushu-u.ac.jp \\ 2フェロー 九州大学教授 大学院工学研究院（广819-0395 福岡県福岡市西区元岡744） \\ E-mail: hashimoto-n@civil.kyushu-u.ac.jp \\ 3学生会員 九州大学大学院工学府（广819-0395 福岡県福岡市西区元岡744） \\ E-mail: tomohiro.yamane@gmail.com \\ 4九州大学大学院工学府（†819-0395 福岡県福岡市西区元岡744） \\ E-mail: kodama@civil.kyushu-u.ac.jp
}

\begin{abstract}
日本沿岸域については温暖化に伴う海水面の上昇に加え，台風の強大化に伴う高波，高潮災害の甚大化 が懸念されている. 本研究では温暖化の影響が先行すると予想される九州沿岸の災害外力の変化特性につ いて，温暖化を考慮した将来の気候予測值（MRI-AGCM3.2S）に基づき検討を行った。 その結果，日本に 接近する台風の数は現在よりも減少するものの, 強大な台風の個数は増える結果となっていることが確認 された。また，風データを基にした波浪推算の結果，常時波浪を含む全データを対象とした比較では波高， 波向ともに現在との差はみられないこと, 年最大波高について比較すると平均值や中央值では同程度であ るものの, 最大波高の小さい年と大きい年の差が大きくなる傾向にあり, 発生しうる最大波高は将来で大 きくなることがうかがえた.
\end{abstract}

Key Words : climate change projection, wave model, coastal disaster,typhoon

\section{1. はじめに}

気候変動に関する政府間パネルの第4次評価報告書 ${ }^{1)}$

（IPCC AR4）において，「気候システムの温暖化には 疑う余地がない」と明言されており，今後の社会資本整 備を考えるうえでは温暖化の影響を考慮した沿岸災害対 策が必須といえる. 日本沿岸域については温暖化に伴う 海水面の上昇に加え，台風の強大化に伴う高波，高潮災 害の甚大化が懸念されている. 文部科学省の 21 世紀気候 変動予測革新プログラムでは, IPCC第5次報告に向けて, 全球気候モデルによる気候変動予測実験が行われており, この気候予測值に基づく沿岸災害の将来変化に関寸る研 究も精力的に進められている例えは2），3）その最新モデル であるMRI-AGCM3.2Sは改良前のMRI-AGCM3.1S と比心 て現在気候の北西太平洋における台風特性の再現性が高 くなっている゙)。本論文では台風の再現性が向上したと されるMRI-AGCM3.2Sの予測值（SRES-A1Bシナリオ） に基づき，日本沿岸域，特に温暖化の影響が先行すると 予想される九州に着目し，将来（2075-2099） と現在 （1979-2003）を比較することにより，台風の発生特性及
び波浪特性の変化について検討した結果を報告する.

\section{2. 台風に着目した検討}

\section{(1) 最低気圧の分布特性}

現在，将来のそれぞれ25年間における期間中の最低気 圧分布（海面更正気圧，6時間毎）を図-1に示寸．現在， 将来ともに北緯35度以南には最低值が $900 \mathrm{hPa}$ 以下であっ たことを示寸紫色のエリアが広く分布しており，台風の 発生経路に対応しているものと考えられるが，特に将来 で紫の部分が多い，また，日本海周辺をみると現在では 黄色（960～980hPa）のエリアが多くみられるが，将来 では黄緑色（940～960hPa）のエリアが多くみられる. このことから, 将来は現在に比べ, より強力な台風が発 生する確率が高くなること，台風が勢力を保ったまま本 州に近づくケースが増えることが示唆される.

台風の来襲発生特性の変化をより詳細に検討するた め, 日本列島に接近寸る台風の個数, 強度, 時期を整理 した.ここでは各年の5月から11月の期間を対象とし， 
北緯35度以南において中心気圧が985hPa以下である低 気圧を台風と定義し，6時間毎の海面更正気圧分布から 中心気圧が995hPaを上回るまで追跡し，中心位置の移動 経路を求めた.

\section{（2）台風の発生特性}

現在および将来について図-2に経度別，緯度別に設定 した7個及び11個のエリアを台風の中心が通過した頻度 を通過時の中心気圧別に整理したものを 図-3，図-4に 示寸，台風の発生頻度についてみると日本列島付近、特 に九州を通過する台風は将来で減少する傾向にあること がわかる. しかしながら, 緑色で示寸強大台風（中心気 圧が900hPa以下）の個数は増加している. 台風経路の変 動についてみると, 経度方向では950hPa以上の台風が東 よりを通過する割合が将来で高くなる様子がみられるも のの，950hPa以下の台風を含めた全体でみると現在と将 来で明瞭な違いは確認できない，なお，本検討ではデー 夕数が少ないため経度の分割幅を 5 度間隔として頻度を 整理していることから，1度程度の移動については傾向 として確認できなかった可能性もある. 緯度方向につい ても全体としての移動傾向はみられないが，赤で示す 950hPa以下の台風については将来で高緯度まで確認され ていること，九州に該当するエリア4では緑で示す 900hPa以下の頻度が増加していることから勢力を保った まま北上する台風が増加する可能性が示唆される.
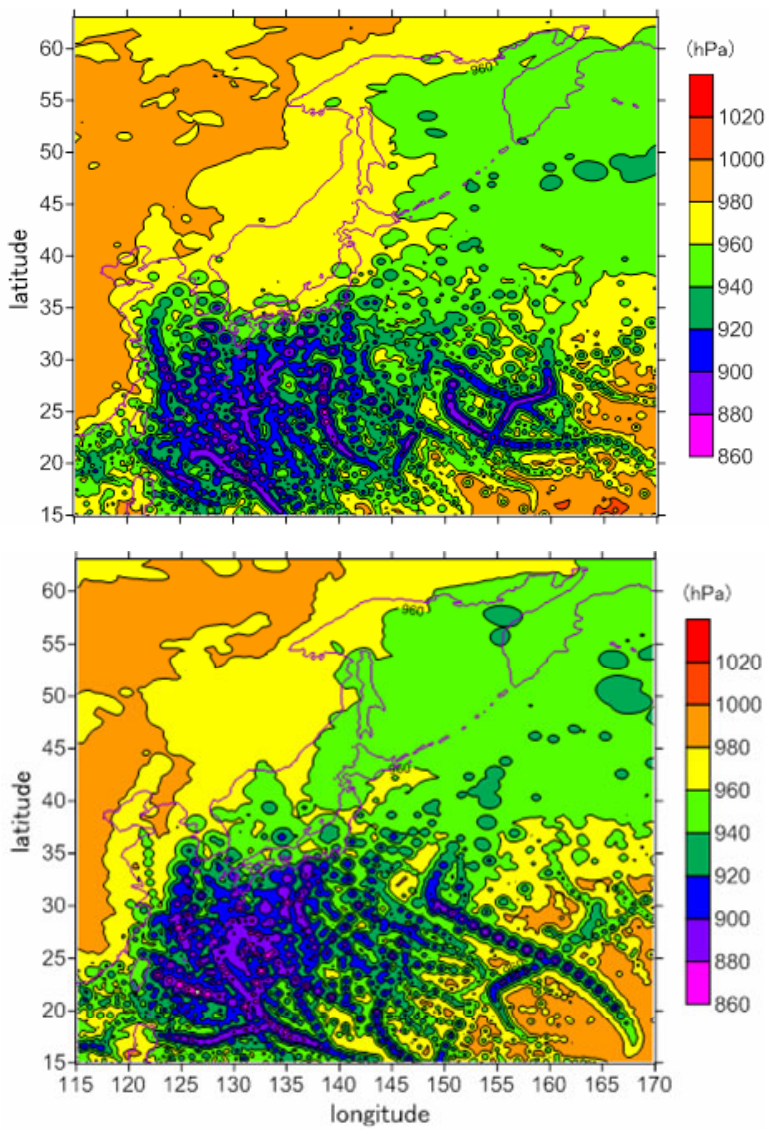

図-1 最低気圧分布（上図 : 現在，下図 : 将来）

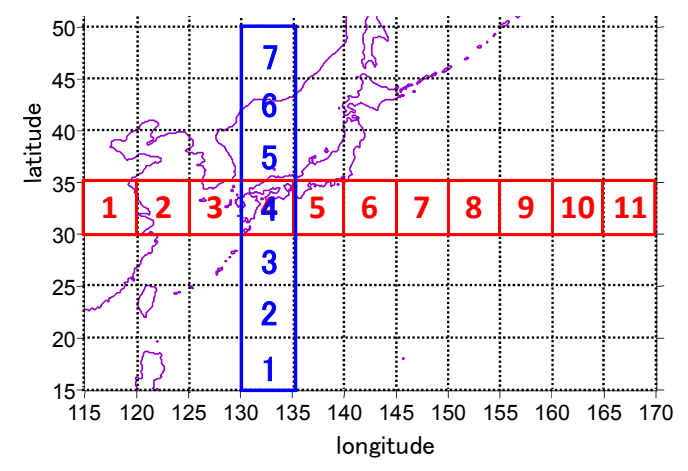

図-2 台風通過頻度整理の設定エリア
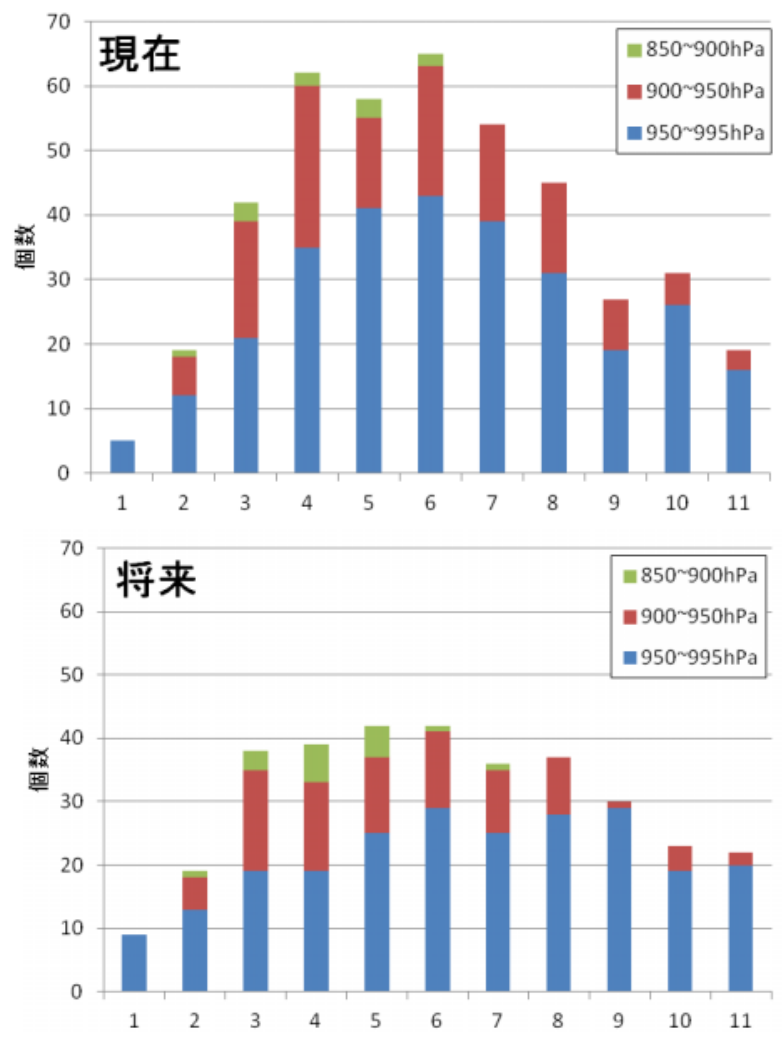

図-3 経度別台風通過頻度（上図 : 現在，下図 : 将来）

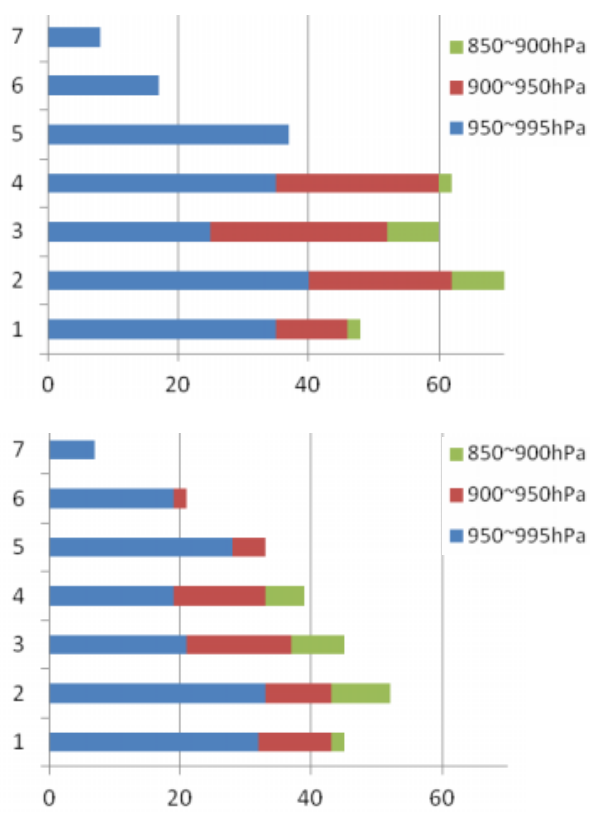

図-4 緯度別台風通過頻度（上図 : 現在, 下図 : 将来) 


\section{3. 波浪に着目した検討}

日本沿岸の波浪特性の変化について検討するため, 現 在及び将来それぞれ 25 年間について風速データ（u，v成 分表示，1時間毎）を外力条件として波浪推算を実施し た．波浪推算モデルはWAMを用い，計算範囲を東経115 $\sim 150$ 度, 北緯 $15 \sim 50$ 度, 計算格子幅を 0.5 度とし, 風か ら波へのエネルギー入力項における摩擦速度の算定につ いては海面抵抗係数を与えるWuの式を適用した。

\section{（1）日本周辺における波高の分布}

現在及び将来についてそれぞれ期間中の有義波高の平 均值分布は図-5に示寸とおりであり，将来，現在ともに 概ね同様の分布となっていることがわかる。 これに対し
て有義波高の最大值分布は図-6に示寸とおりであり，将 来と現在で分布形状が異なっていることがわかる．これ は有義波高の最大值が予測された台風の経路に依存して いることによることがうかがえるが，現在と将来を比較 すると将来で大きい傾向があり, 前述の台風に着目した 検討と同様に将来, 強大台風が増加する結果を反映して いるものと考えられる．図一-7は月最大有義波高（25年間 で300個）の平均值を分布で示したものである. 将来と 現在は概衫同様の分布を示しているものの，各エリアの 波高を比較すると将来で小さい傾向がうかがえる．この ことから高波浪の発生頻度自体は減少していることが推 察されるが，これについては台風の発生頻度が減少した ことが要因と考えられる.
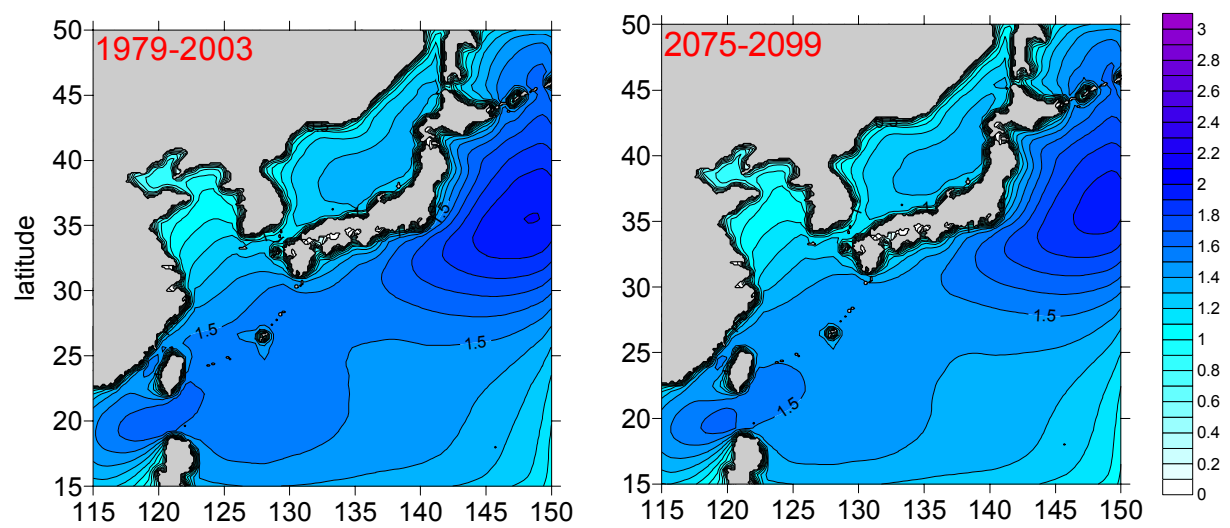

図-5 平均波高分布 (左図 : 現在, 右図 : 将来, 単位 [m] )
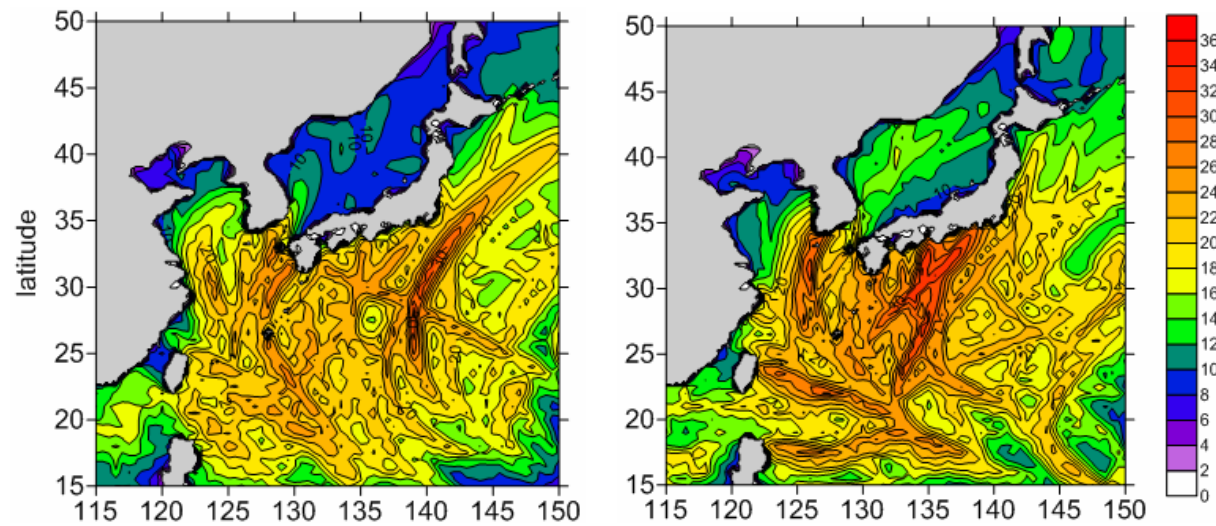

図-6 最大波高分布（左図 : 現在，右図 : 将来，単位 [m]）
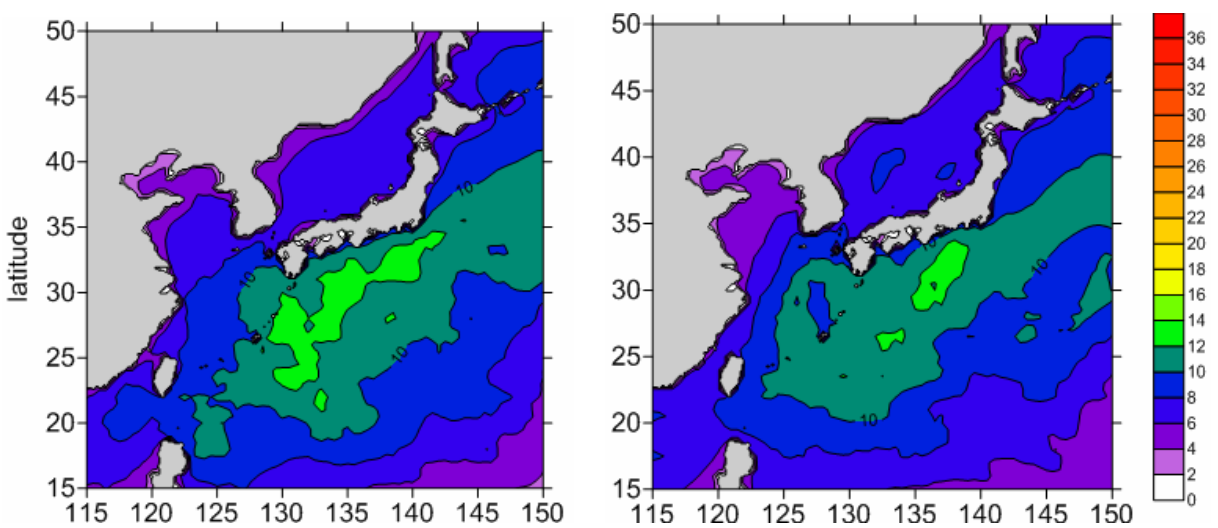

図-7 月最大波高分布 (左図 : 現在, 右図 : 将来, 単位 $[\mathrm{m}]$ ) 


\section{（2）九州における波浪特性の変化}

以下では九州に着目し，図-8に示寸日本海側（玄界 灘）及び太平洋側（鹿児島沖）の2地点について，波浪 推算結果に基づくより詳細な検討を行う。

\section{a) 波高の変化特性}

各地点における年最大有義波高の経年変化を図-9に青 破線で示寸．図中には赤実線で年平均有義波高の時系列 を併せて示している．両地点ともに年変動は大きくばら つく傾向がみられるが，現在及び将来の各期間内におけ る明確なトレンドはみられない. 日本海側, 太平洋側と もに発生する波高の最大值は増大し，特に有義波高が大 きい太平洋側で増大幅も大きいことがわかる.

ここで，年最大有義波高（各期間で計25個ずつ）につ いて波高の小さいものから順にプロットし累積確率分布 関数として整理したものを図-10に示寸. 図中にはそれ ぞれ毎時データの累積確率分布関数もあわせて示してい る. 毎時データの分布についてみると, 両地点ともに各 波高の発生確率は同程度であるといえる. 将来, 現在と もに $50 \%$ で示される中央值は $1 \mathrm{~m}$ 程度であり, 有義波高 が3mを超える頻度は鹿児島沖で4\%程度，玄界灘で $\%$ 程度であった。

年最大值についてみると，立界灘では中央值付近まで は現在と将来で大きな差がみられないものの, 期間中の 最大值が $12 \mathrm{~m}$ から $14 \mathrm{~m}$ と上昇している. 高波の発生確率 でみると年最大值が $10 \mathrm{~m}$ 超える割合が $13 \%$ から $25 \%$ に 増加していることがわかる，鹿児島沖では年最大值が 20mを超える割合が大きく増える一方で, 年最大值が 10mを超える割合は $55 \%$ から $45 \%$ とやや減少しており， 将来は年による最大波高のばらつきが大きくなっていた.

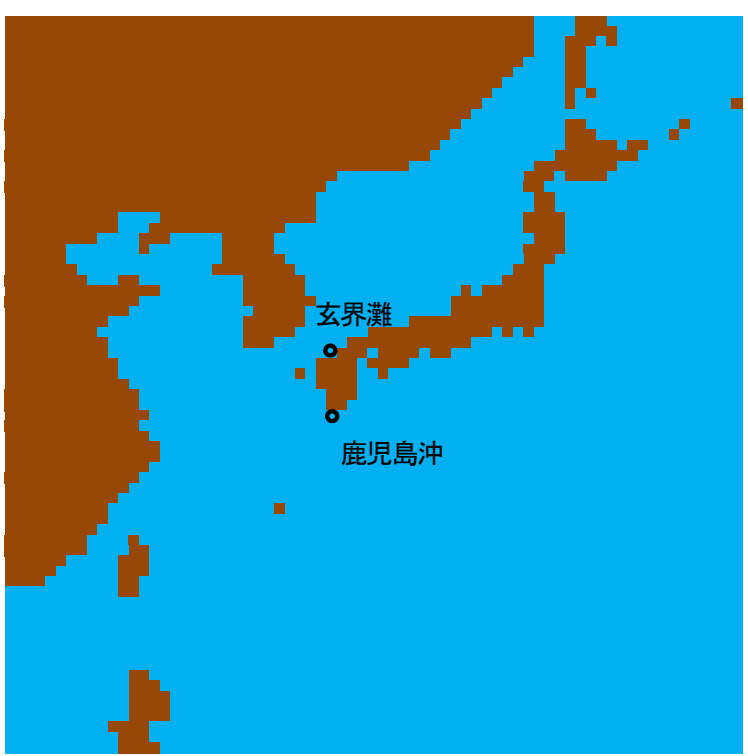

図-8 計算領域と検討対象地点

\section{b) 波向の変化特性}

玄界灘及び鹿児島沖における季節別の波向頻度解析結 果を図-11に示す．両地点とも季節により波向が大きく 異なることがわかるが，青で示寸現在と赤で示寸将来の 頻度分布を比較するとほぼ一致する結果となっており， これら2地点では波向の変化はないものと考えられる.
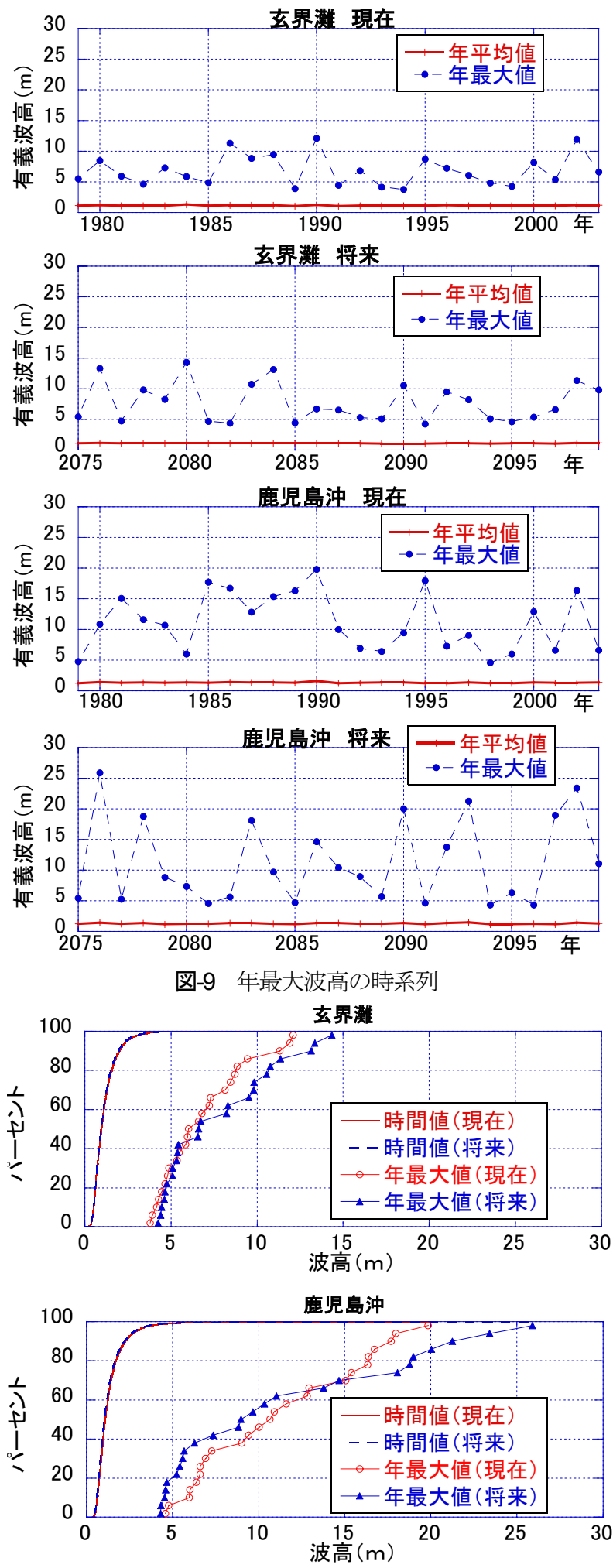

図-10 累積確率分布関数による比較 


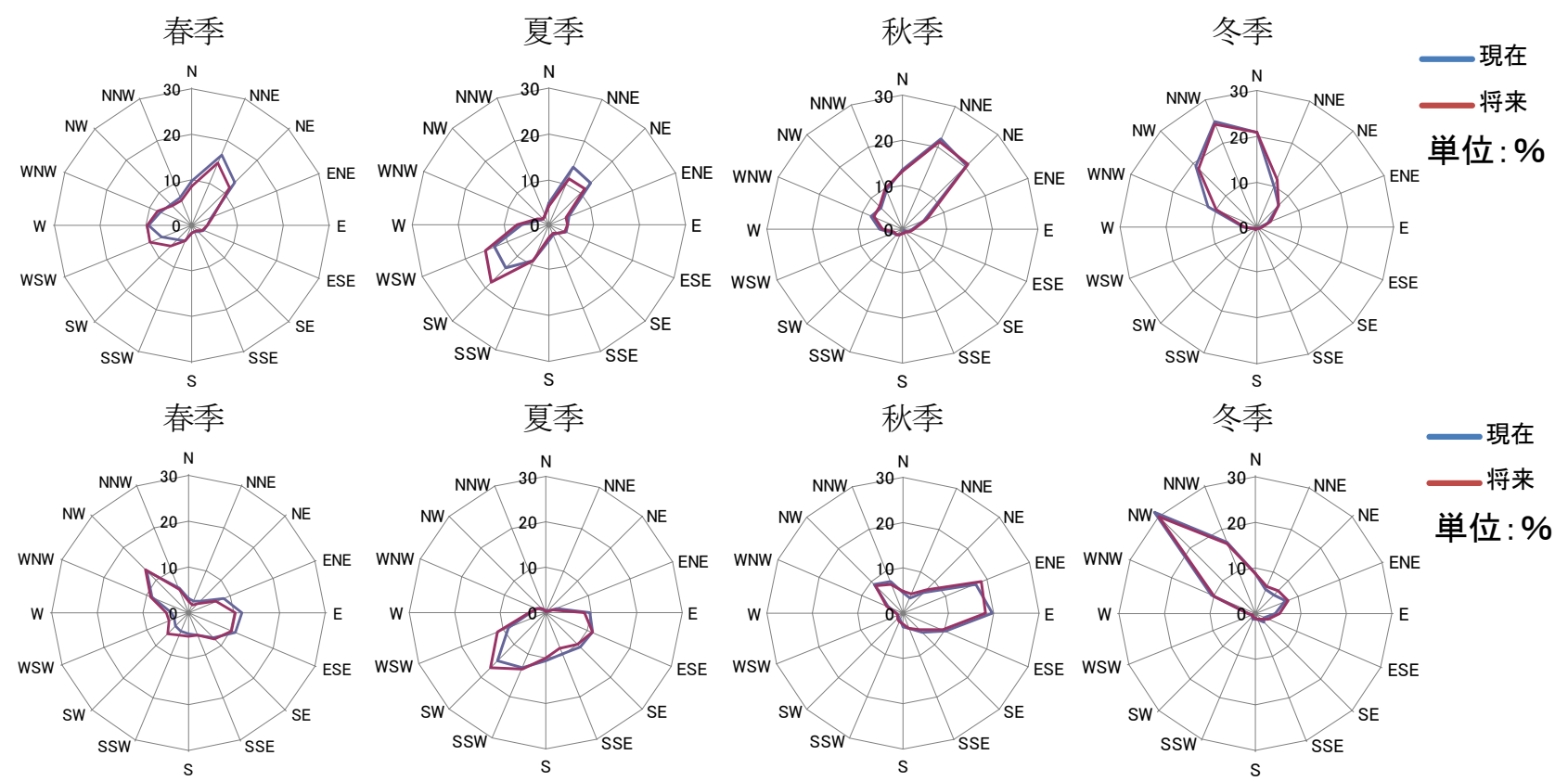

図-11 波向頻度分布の比較（上段 : 玄界灘, 下段 : 鹿児島沖)

\section{4. おわりに}

九州沿岸の災害外力の変化特性について, 温暖化を考 慮した将来の気候予測值に基づき検討し，以下の結果を 得た。

-日本に接近する台風の数は現在よりも減少するもの の, 強大な台風の個数は増える.

・風データを基に実施した波浪推算によれば，常時波 浪を含む全データを対象とした統計的比較では波 高，波向ともに現在との差はみられない.

・年最大波高について比較すると平均值や中央值では 同程度であるものの，最大波高の小さい年と大き い年の差は大きくなる傾向にあり，発生しうる最 大波高は将来で大きくなることがうかがえた.

以上より，沿岸災害の発生頻度は下がる可能性もある ものの，大災害が発生するリスクは高まると想定し，適 応策を検討していく必要があるものと考えられる.
グラム，科学研究費補助金および環境省環境研究総合推 進費(S-8-2(2)亜熱帯化先進地九州における水・土砂災害 適応策の研究)の支援のもと実施された. ここに感謝の 意を表す。

\section{参考文献}

1) IPCC : IPCC Fourth Assessment Report: Climate Change 2007 (AR4)

2) 森信人, 岩崎亮太, 安田誠宏, 間瀬肇, T. Tracey： 地球温暖化予測に基づく全球の海上風・波浪の変化 予測, pp.1271-1275, 海岸工学論文集, 第 56 巻, 2009.

3) 森信人, 志村智也, 安田誠宏, 間瀬肇 : 地球温暖化 に伴う極大波高の将来変化予測, pp.1231-1235, 土木 学会論文集 B2（海岸工学）, Vol.66, 2010.

4) 安田誠宏, 仲條壮大, 金洙列, 森信人, 間瀬肇,Kevin Horsburgh : 気候変動予測実験出力を直接用いた高潮 リスクの評価, pp1171-1175, 土木学会論文集 B2（海 岸工学) , Vol67, 2011.

謝辞 : 本研究は文部科学省 21 世紀気候変動予測革新プロ

\title{
STUDY ON THE CHARACTERISTIC OF COASTAL DISASTER RISK AROUND KYSHU ISLAND BASED ON CLIMATE CHANGE PROJECTION
}

\author{
Masaki YOKOTA, Noriaki HASHIMOTO, \\ Tomohiro YAMANE, and Mitsuyoshi KODAMA
}

The Fourth Assessment Report of the Intergovernmental Panel on Climate Change (IPCC AR4) stated that "Warming of the climate system is unequivocal". In considering the countermeasures against the possible disasters, the global warming has to be taken into account. Not only a sea level rise, but also dis- 
astrous storm surges and destructive high waves accompanied by tremendous typhoons must be the urgent issues. In this study, on the basis of the experimental projection results simulated with the Atmospheric Global Climate Model (MRI-AGCM3.2) of the Innovative Program of Climate Change Projection for the 21th Century, we analyzed the climate data to clarify the changing trend of disaster scale around Kyushu district where the influence of the Global Warming might be found earlier than the other areas in Japan. As a result, it is clarified that the number of severe typhoon that approaches Japan will increase though the total number of typhoon that approaches Japan will decrease. Furthermore, it is found that the occurrence frequency of high waves tends to decrease though the maximum wave height will be higher. 